\title{
Research of Tao Kingship school management thinking and realistic value
}

\author{
Lin Dong ${ }^{1, a}$ \\ ${ }^{1}$ Primary School Headmaster Training Object in Jilin Province, Changchun 130022,China \\ a LinDong2013@yeah.net
}

Keywords: Tao's education thought; education management; school management

\begin{abstract}
Tao xingzhi (1891-1946) is the great people's educators, education thinker and education reform practitioners; he is great patriotic, great democratic fighters and communist fighter. Tao's life had been engaged in a lot of education practice, forming the unique education theory and the education thought, his unique education theory laid in our country's history of Tao's position, he is called "people's educators," "eternal exemplary virtue" [1]in our country. Tao's not only a influence education thinker, but also he has rich experience in running the school administrators. His education management thought is a piece of beautiful gem in China's education heritage, but currently? There a few of about Tao xingzhi's thought in education management research achievements, and education theory research results not only quantity is less, and lack of systematic.
\end{abstract}

\section{Introduction}

Tao xingzhi's thought education management education to the status of ascension to the relationship between the overall quality and national people's rise and fall the height of the honor or disgrace, characterized by The Times and long life. Our country is faced with the education management of business in challenges and questions, the urgent need to we continue to inherit and develop the Tao xingzhi's education management thought essence, he explores the out a foil of ideal bright, and accord with Chinese characteristic school education management approaches to education in the dark ages for the people who struggle with light and hope, until today, still shine a light.

\section{Tao's school management thought}

This part focuses on education management of Tao xingzhi's thought of meaning, and three most is discussed, and the first section discusses school education management thoughts of the basic contents, it includes: the principal subject, teacher education, students participate in view and campus culture; The second section discusses the essential characteristic of school management thought, with the traditional education management through the analysis phase difference between Tao xingzhi's thought the inherent characteristics of management; thus effectively prove education of management thought Tao's rationality and advanced, further excavate the popular education Tao's as the core of the school education management thinking of the meaning and enlightenment.

\section{Basic contents of Tao's school management}

\section{Principal subject}

Principal subject contain mainly democracy. Tao advocated democracy and democratic management of school education, emphasizing a school should not have a dictatorial president, but support the democratic style which means listen to the views from teachers and students to improve scientific decision-making and management levels. He points out that the deep past authoritarian ideology no longer meet the trend of the times, the concept of a democratic republic has long been popular, and so the implementation of democratic management is the trend. Tao requires every president must be in contact with the surging democratic life of democracy, in the wave of democratic experience of democracy in a democratic atmosphere to learn democracy. Tao asks the majority of principals to learn the contents of a new democratic style points. First, to establish the 
idea for your people to ensure status of the subject of education; Second, the implementation of the idea "for the students"[2] education for the public, establish a vision for a better education; Third, listen to all suggestions and avoid arbitrary dictatorship; Fourth, accept criticism and guidance readily; Fifth, provide opportunity for others to discuss all things proceed.

\section{Teacher education}

"To teach people who teach themselves".[3] Tao thinks teachers should enjoy the pleasure of teaching. And one has to learn to remind oneself every day to fill their wisdom, which would also be able to make their own on the podium handy. The practice will keep them do the job longer. At the same time tells teacher to" teach and learn side by side and keep studying."[4] The second point is put the students in the center of everything in the process of teaching, teachers should fully understand before making learning needs of students. The third point is put teach and self-learn side by side. In the process of seeking knowledge, try to form a network access, and then get a wider range of knowledge. Tao insists that only through continuous study can one achieve progress in life.

3. Students participation

Students' participation mainly means students' self-governess. Tao promote "self-governess" that include the following three points: First, the school's students are required to participate without exception; Second, be strict with themselves to develop a habit of self-management; Third, practice self-training exercise capacity in school.

\section{Campus culture}

Tao persists in building a harmonious campus environment and establishing of scientific management rules and regulations. Tao thinks that environment has great effect on people's role, and a democratic school should have a harmonious campus environment which includes campus cultural environment and cultural atmosphere of the building. The environment can cultivate students' ideological and moral purification, thus forming common ideals and beliefs. School management as an extremely important part of the means to make full use of environmental education, cultural environment plays a subtle role which reflects the school civilized healthy development goals.

\section{Characteristics of Tao's school management}

\section{A reflection of the civilization and cohesion}

Tao is quite critical in traditional educational management education which he takes as single ruling class service awareness. In his mind, education is not just a political tool to advocate education and the public combined with the social production. On the contrary, the implementation of the educational system should provide everyone $\mathrm{c}$ access to education as a starting point to a further field.

\section{A reflection of creative and revolutionary idea}

Tao's educational management activities put forward creative educational management theory and methods consistently throughout the journey. He focuses on the promotion of development of the students' creative thinking and creative talent.

\section{A reflection of expansibility and inclusiveness}

Tao's education management focuses on improving the whole nation's ideological and overall quality of the nation. He sketches a blueprint of total governance and shared education which contains lifelong learning in the education management practice. Put the achieving of the modernization of the country as a whole goal through the idea of "a world for the people".[5]

\section{Improve managers' morality and principals' professional level}

Under the context of China's current education management development and reform, there are still many problems exist in the construction of principal management. The main expression is the incomplete principal management system, the lack of systematic thinking in institutional and principal framework building, and the lack of advanced scientific theory as a guide in the principal management system, all the mentioned aspects needed to be further improved and developed. As for the arsing problems occurred in Professional development for principals in the process, we need to improve in the following parts: First of all, strengthen the president's own moral qualities; 
Secondly, strengthen principals' own capacity building, and promote principals' own professional skills. Finally, strengthen principals specialized training, and put the focus on relevance and effectiveness training of the principals.

\section{Tao's realistic value of research}

This part based on the current school management of the actual and the existing problems and puts forward into the twenty-first century Chinese education, in school education management development and reform must rely on education management theory innovation and the education management practices to promote the further advance, the current our country school education management appear in the process of the a series of problems, such as the problem education management system and concepts backward, the subject and object of education management responsibilities chaos, purpose is not clear, around the principal, teachers and students and their parents in education management process of the position is not clear, related to promote its development and sound system is lacking, and so on, it is because of these problems, which caused a lot of contemporary education workers in education management school education theory and the process of education practice of separation, makes education management of the lack of a kind of internal drive mechanism and development of space system in part shows that China's current school education management development and reform still lack true inner education management values. Mining of management thought Tao xingzhi's real value, for school management concept of fresh infuse new vitality, for better constructing harmonious teachers, students' development mechanisms provide reference way, for school management system innovation and the improvement of the quality of individual managers bring experience for reference.

\section{Summary}

In modern society, the school management is a complex and specialized activity that requires principals continue to improve their management philosophy, and improve their knowledge and ability structure. Tao explores the school management thinking and practice, support educational management and theory in the sense of the principal theories. He presented unique insights on the new educational reform concepts such as school management, promotion of a harmonious atmosphere among teachers, students and campus culture, which provides many useful lessons for modern education. In the implementation of the application level, Tao makes it possible that education management researchers deepening of educational management theory expound further, management practitioners constantly reflect. Tao make him as a model and promote education management reform to continue moving forward consciously, help to ensure scientific decisionmaking and rationality, thereby enhancing the effectiveness of management.

\section{References}

[1] Hongyu Zhou. Kingship, Tao's research overseas [M].Beijing, People's Education Press, 1991:138-139, 162,173-174.

[2] Linxiang, Jin. Kingship, Tao's research in the twentieth's century[M].Shanghai, Shanghai Education Press,2005:249, 261-261.

[3] Tao memorial, Tao’s collection [M].Nanjing: Jiangsu Education Press,2001:533.

[4] Ming Fang, The complete works of Tao[M] Sichuan Education Press, 1991: 246

[5] Zhengping Tian, Lang Xiao, Interpretation of Chinese classic education work, Shanghai Education Press, 563 